\title{
REVIEW
}

\section{Heart rhythm disorders and myocardial remodeling in patients with ST-segment elevation acute myocardial infarction}

\author{
Razvan O. Mada', Horia Rosianu', Cristina Mada', Adrian C lancu'
}

\begin{abstract}
Acute myocardial infarction is a potential life threatening disease spread all over the world. The continuing progress of medical and interventional therapies requires a comprehensive understanding of the underlying pathophysiology. Moreover, the potential development of heart failure or/and arrhythmias in either acute or chronic setting, demand a deep knowledge of their molecular mechanisms in order to provide adequate treatments. This review aims to summarize the current data regarding the etiopathogenesis of acute myocardial infarction and the heart rhythm disorders associated with this clinical condition.
\end{abstract}

Keywords: acute myocardial infarction, inflammation, arrhythmias, heart rhythm disorders.

Rezumat: Infarctul miocardic acut este o afecțiune amenințătoare de viață, larg răspândită în întreaga lume. Progresul terapiilor medicale și intervenționale necesită o bună înțelegere a fiziopatologiei de bază. Mai mult decât atât, dezvoltarea potențială a insuficienței cardiace sau / și a aritmiilor, fie în cadru acut sau cronic, necesită o cunoaștere profundă a mecanismelor moleculare pentru a oferi tratamente adecvate. Această revizuire își propune să rezume date actuale privind etiopatogeneza infarctului miocardic acut și a tulburărilor de ritm cardiac asociate aceastei afecțiuni.

Cuvinte cheie: infarct miocardic acut, inflamație, aritmii, tulburări de ritm cardiac.

\section{INTRODUCTION}

ST-segment elevation acute myocardial infarction (STEMI), the most severe form of ischemic heart disease, is one of the leading causes of mortality in the world. This patient population usually dies from either heart rhythm disorders or heart failure ${ }^{1,2}$. The exact underlying pathophysiology of the acute myocardial infarction (AMI) has not been fully understood yet. However, recent data have brought to the spotlight the role of inflammation in the development and further evolution of this severe pathology ${ }^{3}$. This review synthesizes the current knowledge in what concerns the pathophysiology of $\mathrm{AMI}$ and the subsequent heart rhythm disorders, as well as possible future perspectives.

\footnotetext{
' „Niculae Stancioiu” Heart Institute, Cluj-Napoca, Romania
}

\section{ACUTE MYOCARDIAL INFARCTION}

According to the Fourth Universal Definition, type I ST-segment elevation acute myocardial infarction results from a complicated atherosclerotic coronary plaque leading to occlusion or subocclusion of the involved artery'.

The subsequent ischemia leads to myocardial interstitial edema and even necrosis whenever the coronary blood flow is not timely restored. However, even effective percutaneous coronary intervention $(\mathrm{PCl})$ performed in the therapeutic window with complete blood flow restoration has the potential to induce myocardial damage due to the reperfusion injury, ${ }^{4,5}$.

Recent data have shown that large epicardial vessels are not the only responsible for the tissue injury in STEMI. A microvascular obstruction (MVO) is found

\section{Contact address:}

Razvan O Mada, MD, „Niculae Stancioiu” Heart Institute,

19-2I Motilor Street, 40000I, Cluj-Napoca, Romania.

E-mail: mada_razvan@yahoo.com 
in most of the cases. Moreover, in a significant proportion of subjects, MVO leads to intramyocardial hemorrhage, associated with high risk of complications and adverse outcome ${ }^{6-12}$.

Short and long term prognosis is also linked to infarct location, size, and collateral circulation. They appear to be major determinants of the left ventricular

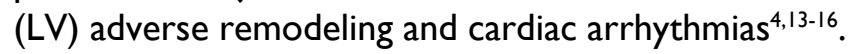

\section{ROLE OF INFLAMMATION}

Current data suggest a complex relationship between inflammation and cardiac remodeling, respectively arrhythmogenesis $^{17-20}$.

Inflammation holds a key role in tissue healing. Its involvement in the preclinical phase and post reperfusion evolution of patients with STEMI has been extensively evaluated in recent studies. Apparently, the same inflammatory mechanisms responsible for tissue healing, if not adequately controlled, have the potential to induce adverse ventricular remodeling. The rapid complement cascade activation subsequent to the ischemic injury stimulates different pathways signaling tissue damage. Further activation of the nuclear factor-kB and inflammasomes provides essential elements of the cytokine response to AMI. Moreover, the embolisation of inflammatory material from unstable plaques into the distal microcirculation before reperfusion therapy may represents another potential source of inflammatory triggers ${ }^{3,21-24}$.

In STEMI, hours to days before the clinical onset, the fresh thrombus is unstable and may embolise into the distal microcirculation, generating pre procedural MVO and/or interstitial inflammatory injury. Additionally, the significant recruitment of neutrophils and the production of cytokines, chemokines and other proinflammatory stimuli during the ischemia-reperfusion process is involved in the development of microvascular dysfunction" ${ }^{\prime}$. The irreversible microvascular damage and subsequent intramyocardial hemorrhage leads to iron deposition within the myocardium ${ }^{25}$.

However, local inflammation is only one of the multiple mechanisms involved in arrhythmogenesis. Systemic inflammation also appears to play a significant role through a variety of direct and indirect pathways such as:

- induction of ischemic heart disease

- myocardial dysfunction

- cytokine effect

- activation of systemic coagulation response

- bacterial components (endotoxins) ${ }^{17-20}$

In the setting of either acute or chronic myocardial ischemia, the electrical vulnerability results from the interaction between the injured myocardium (with altered electrophysiological properties) and the particular biohumoral "atmosphere". The later is characterized by sympathetic activation, high level of catecholamine, metabolic residues and proinflamatory elements (such as CRP, IL-I, IL-6, IL-8, TNF- $\alpha$, etc) 18,20,26-28

Severe systemic inflammation has the potential to induce myocardial dysfunction, a well-known arrhythmogenic trigger. Increased wall stress and proinflamatory cytokines (as mentioned above) appear to promote heart rhythm disorders in arrhythmia-prone patients (with STEMI, cardiomyopathy, etc), possibly by reducing the arrhythmogenic threshold ${ }^{18,20,29,30}$.

Moreover, proinflamatory cytokines influence both coagulation and fibrinolytic systems promoting the proper environment for arrhythmia development. On the other hand, a number of hemostatic markers are associated with new-onset atrial fibrillation supporting the hypothesis that endothelial dysfunction and oxidative stress are potential indirect arrhythmogenic mechanisms ${ }^{31-33}$.

Despite recent advances, the underlying pathophysiology of infarction-related arrhythmias is not fully understood and further studies are needed.

\begin{tabular}{|l|l|l|}
\hline Table I. Heart rhythm disorders associated with acute myocardial infarction. \\
\hline Supraventricular arrhythmias & Ventricular arrhythmias & Conduction abnormalities \\
\hline Sinus tachycardia & Premature Ventricular Contractions & $\begin{array}{l}\text { Atrioventricular Blocks (first, second and } \\
\text { third degree) }\end{array}$ \\
\hline Sinus bradycardia & $\begin{array}{l}\text { Accelerated } \\
\text { Idioventricular } \\
\text { Rhythm }\end{array}$ & $\begin{array}{l}\text { Intraventricular Blocks (left anterior fascicular } \\
\text { block, right bundle branch block, left bundle } \\
\text { branch block) }\end{array}$ \\
\hline Atrial fibrillation & $\begin{array}{l}\text { Sustained/Non-sustained Ventricular } \\
\text { Tachycardia }\end{array}$ & \\
\hline Atrial flutter & Ventricular Fibrillation & \\
\hline Premature atrial contractions & & \\
\hline Paroxysmal supraventricular tachycardia & & \\
\hline Accelerated junctional rhythms & & \\
\hline Junctional bradycardia & & \\
\hline
\end{tabular}




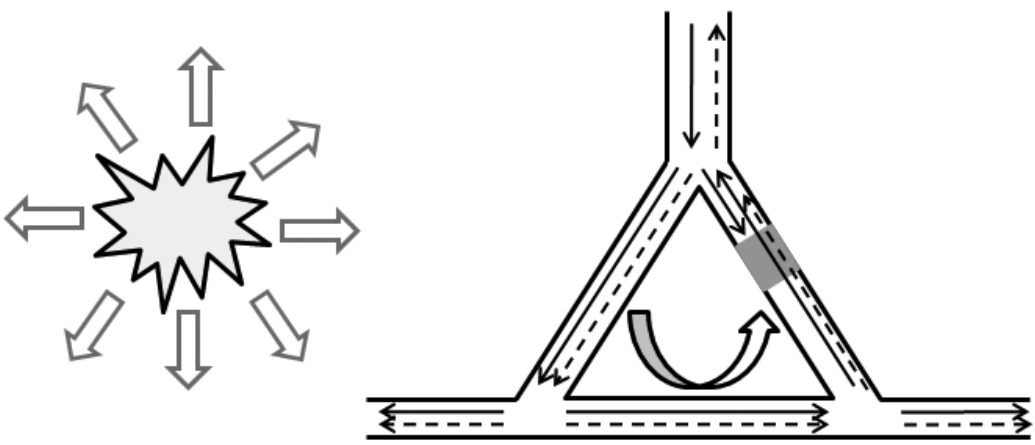

Abnormal automaticity

Re-entry

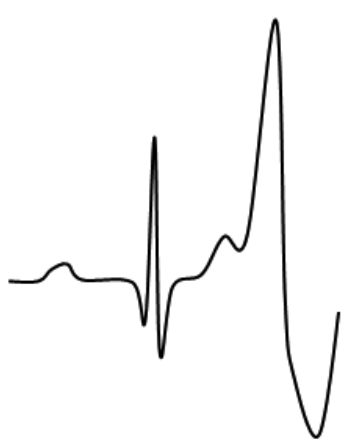

Triggered activity

Figure I. Arrhythmia mechanisms in patients with acute myocardial infarction:Abnormal automaticity - Spontaneous depolarization outside the sinoatrial node. Re-entry - Wave fronts travelling around an area of unidirectional block and reexcitement of previously activated cardiomyocytes (unidirectional block - grey area). Triggered activity - Oscillations in membrane voltage induced by one or more preceding action potentials.

\section{HEART RHYTHM DISORDERS}

During AMI, local and systemic conditions provide a suitable environment for a variety of rhythm and conduction disorders as shown in Table $\mathrm{I}^{34,35}$. The complex interaction between the arrhythmogenic triggers and the proarrhythmic substrate supports any of the classical arrhythmogenic mechanisms: abnormal automaticity, triggered activity and re-entry (Figure I) $)^{26,36,37}$.

\section{Supraventricular arrhythmias}

With the exception of sinus bradycardia / tachycardia and atrial fibrillation / flutter, all other supraventricular arrhythmias are uncommon during myocardial infarction ${ }^{34,35}$.

Spontaneous activity of the sinoatrial node is under neurogenic (parasympathetic and sympathetic nervous system) or hormonal control, but a direct modulation of ionic currents by metabolic inhibition is also possible $^{36}$.

Sinus bradycardia is usually present in the first 24 hours of inferior AMI due to increased vagal tone. Uncommonly, it can be found in case of ischemia of the sinoatrial (SA) node, as a reperfusion arrhythmia or after medication ${ }^{38,39}$.

Sinus tachycardia develops soon after symptoms onset and is more common in anterior AMI, usually with impaired LV, reflecting the degree of sympathetic activation $^{40,41}$.

Atrial fibrillation appears usually within the first 72 hours in patients with AMI and significant comorbidities. It has a complex ethiopathogenesis involving atrial dysfunction (atrial ischemia/infarction or atrial stretching), ischemia of the SA and atrioventricu- lar (AV) node, increased sympathetic tone, local and systemic inflammation as well as iatrogenic factors ${ }^{42,43}$.

\section{Ventricular arrhythmias}

Premature ventricular complexes (PVCs), ventricular tachycardia (VT) and ventricular fibrillation (VF) are common in the peri-infarct period. They result from the interaction between the proarrhythmic substrate, modulating factors and arrhythmogenic triggers ${ }^{44-46}$.

Acute ischemia leads to myocardial damage with subsequent alteration of the electrophysiological properties of the myocardial fiber acting as arrhythmogenic substrate. Changes in the action and resting potential of the membrane subsequent to altered transmembrane ionic flow lead to abnormal conduction, refractoriness and automaticity of the myocyte ${ }^{26,36}$. Delayed conduction through a damaged myocardium (as potential substrates for ventricular arrhythmias (VA) re-entry) can be assessed noninvasively using ventricular late potentials (VLPs). They consist of the presence of electrical activity after the end of the standard QRS complex (Figure 2) ${ }^{47}$.

Electrolytic imbalance (hypopotasemia, hypomagnesaemia), ongoing ischemia, impaired left ventricular (LV) function and generalized autonomic dysfunction (increased sympathetic activity associated with high levels of catecholamines) are the modulating fac-

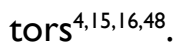

Myocardial stretch short-circuits and injury currents in the border zone, $\mathrm{Ca}^{2+}$ overload in either Purkinje fibers or cardiomyocytes as well as variations in cardiac cycle length act as arrhythmia triggers ${ }^{26,36}$. 


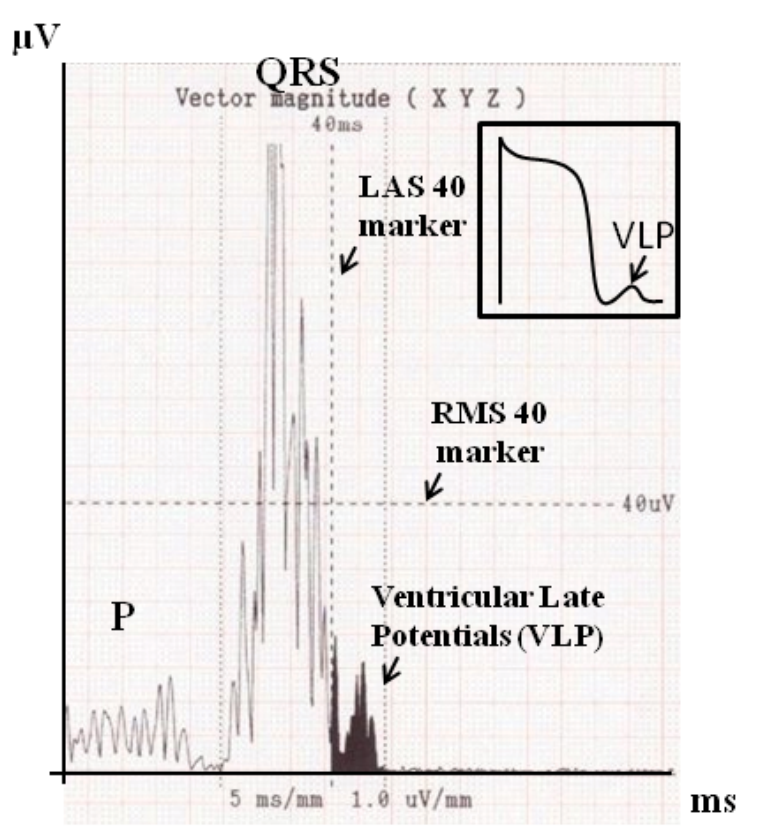

Figure 2. Assessment of the ventricular late potentials using Signal Averaged ECG (3 parameters (average values) derived from multiple beats): filtered QRS duration >II4ms; LAS 40 (=low amplitude $(<40 \mu \mathrm{V})$ signal duration) > 38ms; RMS 40 (=root mean square voltage of the terminal QRS (last $40 \mathrm{~ms}$ ) $<20 \mu \mathrm{V}$. Noise should be minimal (standard deviation of the TP segment $<\mid \mu \mathrm{V})$.

VA in the context of myocardial infarction is the result of the interplay between different events such as ischemia, necrosis, reperfusion, healing, scar formation and autonomic changes. They are responsible for the development and perpetuation of the arrhythmia ${ }^{4,15}$.

Underlying mechanisms of the VA vary with time and have different prognostic implications.

In the early phase, the electrical vulnerability manifests as either polymorphic ventricular tachycardia (VT) or ventricular fibrillation (VF). Experimental data showed that arrhythmias occurring in the first 2 to 10 minutes after coronary occlusion, also called phase Ia VA, have re-entry as dominant mechanism while abnormal automaticity could play a minor role. Rhythm disorders that develop from 10 to 30 minutes after coronary occlusion, also called phase Ib VA, have re-entry as well as abnormal automaticity as likely dominant mechanism ${ }^{36,49}$.

Delayed VAs usually occurs from 6 to $48 \mathrm{~h}$ from STEMI onset. Their dominant mechanism is abnormal automaticity. Triggered activity (due to delayed afterdepolarization) and a combination of abnormal automaticity and re-entry are also possible. The most frequent VA are PVCs, non-sustained VT and accelerated idioventricular rhythm (AIVR) ${ }^{50,51}$.

The time period between the early and delayed phase is characterized by the presence of rare PVCs due to abnormal automaticity ${ }^{26,52,36}$.

VA in some patients is considered to be related to reperfusion, which can be either spontaneous or as a result of medical intervention (thrombolysis or percutaneous coronary intervention). Triggered activity is the dominant mechanism. The typical example is AIVR (which is neither sensitive nor specific for effective reperfusion) ${ }^{26,36,56-60}$.

\section{CONDUCTION ABNORMALITIES}

The most common electrical conduction disorders encountered in AMI are summarized in Table I. They are the consequence of autonomic imbalance (increased vagal tone) or ischemia/infarction affecting the electrical conduction system.

Conduction abnormalities associated with inferior infarction are more common and can develop from presentation up to days. They usually have a benign course.

Those associated with anterior infarction are less common. They are related to the extent of myocardial damage and have prognosis value $\mathrm{e}^{61-63}$.

\section{Perspectives}

A comprehensive understanding of the ethiopathogenesis of a certain disease is a prerequisite for the development of effective therapies. It allows addressing specific targets or particular pathways.

Despite the plethora of medical and interventional therapies available, a significant number of patients with STEMI develop heart failure and sudden cardiac death $^{3}$. The reason why this subgroup has a negative prognosis is still under debate. Preventing adverse cardiac remodeling could reduce the incidence of heart failure and cardiac arrhythmias, with direct impact on survival and quality of life.

The involvement of inflammation as key mechanism, in the genesis of both AMI (with subsequent cardiac remodeling) and cardiac arrhythmias offers new therapeutic perspectives. Several anti-inflammatory drugs that have been tested over time (steroids, nonsteroidal anti-inflammatory drugs, colchicines, cytokine blockers and modulators) ${ }^{22,24,64-66}$. Despite some encouraging results, none have entered daily clinical practice, supporting the need for further research.

Conflict of interest: none declared. 


\section{References}

I. Thygesen K, Alpert JS, Jaffe AS, Chaitman BR, Bax JJ, Morrow DA, White HD and The Executive Group on behalf of the Joint European Society of Cardiology (ESC)/American College of Cardiology (ACC)/American Heart Association (AHA)/World Heart Federation (WHF) Task Force for the Universal Definition of Myocardial Infarction. Fourth Universal Definition of Myocardial Infarction (2018). J Am Coll Cardiol. 2018;72(18):2231-2264.

2. Ibanez B, James S, Agewall S, Antunes MJ, Bucciarelli-Ducci C, BuenoH, Caforio ALP, Crea F, Goudevenos JA, Halvorsen S, Hindricks G, Kastrati A, Lenzen MJ, Prescott E, Roffi M, Valgimigli M, Varenhorst C, Vranckx P, Widimský P, ESC Scientific Document Groupet. 2017 ESC Guidelines for the management of acute myocardial infarction in patients presenting with ST-segment elevation. Eur Heart J. 2018 Jan 7;39(2): I 19-177.

3. Westman PC, Lipinski MJ, Luger D, Waksman R, Bonow RO, Wu E, Epstein SE. Inflammation as a Driver of Adverse Left Ventricular Remodeling After Acute Myocardial Infarction. J Am Coll Cardiol. 2016;67(17):2050-2060.

4. Bhar-Amato J, Davies W, Agarwal S. Ventricular Arrhythmia after Acute Myocardial Infarction: "The Perfect Storm". Arrhythmia Electrophysiol Rev. 2017;6(3):I34-I39.

5. Dumas F, Cariou A, Manzo-Silberman S, Grimaldi D, Vivien B, Rosencher J, Empana J-P, Carli P, Mira J-P, Jouven X, Spaulding C. Immediate Percutaneous Coronary Intervention Is Associated With Better Survival After Out-of-Hospital Cardiac Arrest: Insights From the PROCAT (Parisian Region Out of Hospital Cardiac Arrest) Registry. Circ Cardiovasc Interv. 2010;3(3):200-207.

6. lancu A, Ober C, Bondor $\mathrm{Cl}$, Cadis H. Microvascular Effect of Intracoronary Eptifibatide in Acute Myocardial Infarction. Cardiology. 2012;123(I):46-53.

7. lancu AC, Rafiroiu D, Marc M. Is Coronary Wedge Pressure a Technique to Identify High-Risk Patients Who May Benefit From Alternative Treatment in Acute Myocardial Infarction? JACC Cardiovasc Interv. 2016;9(1):104-105.

8. Patel N, Petraco R, Dall'Armellina E, Kassimis G, De Maria GL, Dawkins S, Lee R, Prendergast BD, Choudhury RP, Forfar JC, Channon KM, Davies J, Banning AP, Kharbanda RP. Zero-Flow Pressure Measured Immediately After Primary Percutaneous Coronary Intervention for ST-Segment Elevation Myocardial Infarction Provides the Best Invasive Index for Predicting the Extent of Myocardial Infarction at 6 Months: An OxAMI Study (Oxford Acute Myocardial Infarction). JACC Cardiovasc Interv. 20I5;8(I I): I4I0-I42I.

9. Ganame J, Messalli G, Dymarkowski S, Rademakers FE, Desmet W, Van de Werf F, Bogaert J. Impact of myocardial haemorrhage on left ventricular function and remodelling in patients with reperfused acute myocardial infarction. Eur Heart J. 2009;30(I2): |440- | 449.

10. Ndrepepa G, Tiroch K, Fusaro M, Keta D, Seyfarth M, Byrne RA, Pache J, Alger P, Mehilli J, Schömig A, Kastrati A. 5-Year Prognostic Value of No-Reflow Phenomenon After Percutaneous Coronary Intervention in Patients With Acute Myocardial Infarction. J Am Coll Cardiol. 2010;55(21):2383-2389.

II. Kramer MCA, van der Wal AC, Koch KT, Ploegmakers JPHM, Van der Schaaf RJ, Henriques JPS, Baan J, Rittersma SZH, Vis MM, Piek JJ, Tijssen JGP, De Winter RJ. Presence of Older Thrombus Is an Independent Predictor of Long-Term Mortality in Patients With STElevation Myocardial Infarction Treated With Thrombus Aspiration During Primary Percutaneous Coronary Intervention. Circulation. 2008; I 18(18): 1810-1816.

12. Hamirani YS, Wong A, Kramer CM, Salerno M. Effect of Microvascular Obstruction and Intramyocardial Hemorrhage by CMR on LV Remodeling and Outcomes After Myocardial Infarction. JACC Cardiovasc Imaging. 2014;7(9):940-952.

13. Euler DE, Spear JF, Moore EN. Effect of coronary occlusion on arrhythmias and conduction in the ovine heart. Am J Physiol - Hear Circ Physiol. 1983; I4(I).

14. Li X, Shao D, Wang G, Jiang T, Wu H, Gu B, Cao K, Zhang J, Qi $L$, Chen Y. Effects of different LAD-blocked sites on the development of acute myocardial infarction and malignant arrhythmia in a swine model. J Thorac Dis. 2014;6(9): 127|-1277.
15. Sattler SM, Skibsbye L, Linz D, Lubberding AF, Tfelt-Hansen J, Jespersen T. Ventricular Arrhythmias in First Acute Myocardial Infarction: Epidemiology, Mechanisms, and Interventions in Large Animal Models. Front Cardiovasc Med. 2019;6.

16. Hreybe H, Saba S. Location of Acute Myocardial Infarction and Associated Arrhythmias and Outcome. Clin Cardiol. 2009;32(5):274-277.

17. Lewek J, Kaczmarek K, Cygankiewicz I, Wranicz JK, Ptaszynski P. Inflammation and arrhythmias: potential mechanisms and clinical implications. Expert Rev Cardiovasc Ther. 2014;12(9):I077-I085.

18. Yalta T, Yalta K. Systemic Inflammation and Arrhythmogenesis: A Review of Mechanistic and Clinical Perspectives. Angiology. 2018;69(4): 288-296.

19. Whayne TF, Morales GX, Darrat YH. Clinical Aspects of Systemic Inflammation and Arrhythmogenesis, Especially Atrial Fibrillation. Angiology. 2018;69(4):28I-285.

20. Vonderlin N, Siebermair J, Kaya E, Köhler M, Rassaf T, Wakili R. Critical inflammatory mechanisms underlying arrhythmias. Herz. 2019;44(2):121-129.

21. Kawashima C, Matsuzawa Y, Akiyama E, Konishi M, Suzuki H, Hashiba K, Ebina T, Kosuge M, Hibi K, Tsukahara K, Iwahashi N, Maejima N, Sakamaki K, Umemura S, Kimura K, Tamura K. Prolonged Fever After ST-Segment Elevation Myocardial Infarction and Long-Term Cardiac Outcomes. J Am Heart Assoc. 2017;6(7):e005463.

22. Ridker PM, Everett BM, Thuren T, MacFadyen JG, Chang WH, Ballantyne C, Fonseca F, Nicolau J, Koenig W, Anker SD, Kastelein JJP, Cornel JH, Pais P, Pella D, Genest J, Cifkova R, Lorenzatti A, Forster T, Kobalava Z, Vida-Simiti L, Flather M, Shimokawa H, Ogawa H, Dellborg M, Rossi PRF, Troquay RPT, Libby P, Glynn RJ, CANTOS Trial Group. Antiinflammatory Therapy with Canakinumab for Atherosclerotic Disease. N Engl J Med. 20 I7;377(I2): I I I9- I I3 I.

23. Li X, Chen C, Gan F, Wang Y, Ding L, Hua W. Plasma NT pro-BNP, hs-CRP and big-ET levels at admission as prognostic markers of survival in hospitalized patients with dilated cardiomyopathy: a singlecenter cohort study. BMC Cardiovasc Disord. 20I4; I4(I):67.

24. Tardif J-C, Kouz S, Waters DD, Bertrand OF, Diaz R, Maggioni AP, Pinto FJ, Ibrahim R, Gamra H, Kiwan GS, Berry C, López-Sendón J, Ostadal P, Koenig W, Angoulvant D, Grégoire JC, Lavoie M-A, Dubé M-P, Rhainds D, Provencher M, Blondeau L, Orfanos A, L'Allier PL, Guertin M-C, Roubille F. Efficacy and Safety of Low-Dose Colchicine after Myocardial Infarction. N Engl J Med. 20I9;38I (26):2497-2505.

25. Kali A, Kumar A, Cokic I, Tang RLQ, Tsaftaris SA, Friedrich MG, Dharmakumar R. Chronic manifestation of postreperfusion intramyocardial hemorrhage as regional iron deposition: A cardiovascular magnetic resonance study with ex vivo validation. Circ Cardiovasc Imaging. 2013;6(2):218-228.

26. Janse MJ, Wit AL. Electrophysiological mechanisms of ventricular arrhythmias resulting from myocardial ischemia and infarction. Physiol Rev. 1989;69(4): 1049-I 169.

27. Wit AL, Friedman PL. Basis for ventricular arrhythmias accompanying myocardial infarction: alterations in electrical activity of ventricular muscle and Purkinje fibers after coronary artery occlusion. Arch Intern Med. 1975; I35(3):459-472.

28. Botting JH, Curtis MJ, Walker MJA. Arrhythmias associated with myocardial ischaemia and infarction. Mol Aspects Med. 1985;8(4):307422.

29. Ruiz-Bailén M, Romero-Bermejo FJ, Rucabado-Aguilar L, PérezValenzuela J, Ferrezuelo-Mata A, Ramírez-Sánchez M, Cuadra JAR, Ramírez MJM. Myocardial dysfunction in the critically ill patient: Is it really reversible? Int J Cardiol. 2010;|45(3):615-6I6.

30. Court O, Kumar A, Parrillo JE, Kumar A. Clinical review: Myocardial depression in sepsis and septic shock. Crit Care. 2002;6(6):500-508.

31. Alonso A, Tang W, Agarwal SK, Soliman EZ, Chamberlain AM, Folsom AR. Hemostatic markers are associated with the risk and prognosis of atrial fibrillation: The ARIC study. Int J Cardiol. 2012; I55(2): 217-222.

32. Mclnnes IB, Thompson L, Giles JT, V Bathon JM, Salmon JE, Beaulieu AD, Codding CE, Carlson TH, Delles C, Lee JS, Sattar N. Effect of interleukin-6 receptor blockade on surrogates of vascular risk in rheumatoid arthritis: MEASURE, a randomised, placebo-controlled study. Ann Rheum Dis. 2015;74(4):694-702.

33. Van Den Oever IAM, Sattar N, Nurmohamed MT. Thromboembolic and cardiovascular risk in rheumatoid arthritis: Role of the haemostatic system. Ann Rheum Dis. 2014;73(6):954-957. 
34. Rosamond W, Flegal K, Furie K, Go A, Greenlund K, Haase N, Hailpern SM, Ho M, Howard V, Kissela B, Kittner S, Lloyd-Jones D, McDermott M, Meigs J, Moy C, Nichol G, O'Donnell C, Roger V, Sorlie P, Steinberger J, Thom T, Wilson M, Hong Y, American Heart Association Statistics Committee and Stroke Statistics Subcommittee. Heart disease and stroke statistics-2008 Update: A report from the American heart association statistics committee and stroke statistics subcommittee. Circulation. 2008;1 I7(4).

35. Gorenek B, Blomström Lundqvist C, Brugada Terradellas J, Camm AJ, Hindricks G, Huber K, Kirchhof $P$, Kuck KH, Kudaiberdieva G, Lin T, Raviele A, Santini M, Tilz RR, Valgimigli M, Vos MA, Vrints $\mathrm{C}$, Zeymer U, Kristiansen SB. Cardiac arrhythmias in acute coronary syndromes: position paper from the joint EHRA, ACCA, and EAPCI task force. Europace. 2014;16(II):1655-1673.

36. Carmeliet E. Cardiac ionic currents and acute ischemia: From channels to arrhythmias. Physiol Rev. 1999;79(3):917-1017.

37. Antzelevitch C, Burashnikov A. Overview of Basic Mechanisms of Cardiac Arrhythmia. Card Electrophysiol Clin. 20I I;3(I):23-45.

38. Adgey AA, Geddes JS, Mulholland HC, Keegan DA, Pantridge JF. Incidence, significance, and management of early bradyarrhythmia complicating acute myocardial infarction. Lancet. 1968;2(7578):1097IIOI.

39. Zimetbaum PJ, Josephson ME. Use of the electrocardiogram in acute myocardial infarction. N Engl J Med. 2003;348(I0):933-940.

40. Crimm A, Severance HW, Coffey K, Mckinnis R, Wagner GS, Califf RM. Prognostic significance of isolated sinus tachycardia during first three days of acute myocardial infarction. Am J Med. 1984;76(6):983988.

4I. Becker RC, Burns M, Gore JM, Spencer FA, Ball SP, French W, Lambrew C, Bowlby L, Hilbe J, Rogers WJ. Early assessment and inhospital management of patients with acute myocardial infarction at increased risk for adverse outcomes: A nationwide perspective of current clinical practice. Am Heart J. 1998; I35(5 I):786-796.

42. Wong CK, White HD, Wilcox RG, Criger DA, Califf RM, Topol EJ, Ohman EM. New atrial fibrillation after acute myocardial infarction independently predicts death: The GUSTO-III experience. Am Heart J. 2000; I 40(6):878-885.

43. Jons $C$, Jacobsen UG, Joergensen RM, Olsen NT, Dixen U, Johannessen A, Huikuri H, Messier M, McNitt S, Thomsen PEB, Cardiac Arrhythmias and Risk Stratification after Acute Myocardial Infarction (CARISMA) Study Group. The incidence and prognostic significance of new-onset atrial fibrillation in patients with acute myocardial infarction and left ventricular systolic dysfunction: A CARISMA substudy. Hear Rhythm. 201 I;8(3):342-348.

44. Bigger JT, Dresdale RJ, Heissenbuttel RH, Weld FM, Wit AL. Ventricular arrhythmias in ischemic heart disease: Mechanism, prevalence, significance, and management. Prog Cardiovasc Dis. 1977;19(4):255300.

45. O'Doherty M, Tayler DI, Quinn E, Vincent R, Chamberlain DA. Five hundred patients with myocardial infarction monitored within one hour of symptoms. Br Med J. 1983;286(6375): I 405-I 408.

46. Tran H V., Ash AS, Gore JM, Darling CE, Kiefe Cl, Goldberg RJ. Twenty-five year trends (I986-20I I) in hospital incidence and casefatality rates of ventricular tachycardia and ventricular fibrillation complicating acute myocardial infarction. Am Heart J. 20 I 9;208: I-I0.

47. Santangeli P, Infusino F, Sgueglia GA, Sestito A, Lanza GA. Ventricular late potentials: a critical overview and current applications. J Electrocardiol. 2008;4I (4):3 I8-324.

48. Bloch Thomsen PE, Jons C, Raatikainen MJP, Joergensen RM, Hartikainen J, Virtanen V, Boland J, Anttonen O, Gang UJ, Hoest N, Boersma LVA, Platou ES, Becker D, Messier MD, Huikuri HV, Cardiac Arrhythmias and Risk Stratification After Acute Myocardial Infarction (CARISMA) Study Group Long-term recording of cardiac arrhythmias with an implantable cardiac monitor in patients with reduced ejection fraction after acute myocardial infarction: the Cardiac Arrhythmias and Risk Stratification After Acute Myocardial Infarction (CARISMA) study. Circulation. 2010; I22(I3): I258-1264.

49. Di Diego JM, Antzelevitch C. Ischemic ventricular arrhythmias: Experimental models and their clinical relevance. Hear Rhythm. 20I I; $8(12): 1963-1968$.
50. Campbell RWF, Murray A, Julian DG. Ventricular arrhythmias in first 12 hours of acute myocardial infarction. Natural history study. $\mathrm{Br}$ Heart J. 198I;46(4):35I-357.

5I. Northover BJ. Ventricular tachycardia during the first 72 hours after acute myocardial infarction. Cardiol. 1982;69(3): I49-156.

52. Marchlinski FE, Buxton AE, Waxman HL, Josephson ME. Identifying patients at risk of sudden death after myocardial infarction: Value of the response to programmed stimulation, degree of ventricular ectopic activity and severity of left ventricular dysfunction. Am J Cardiol. 1983;52(10): I 190-I196.

53. Marchlinski FE, Buxton AE, Waxman HL, Josephson ME. Identifying patients at risk of sudden death after myocardial infarction: Value of the response to programmed stimulation, degree of ventricular ectopic activity and severity of left ventricular dysfunction. Am J Cardiol. 1983;52(10): I 190-II 196.

54. DiMarco JP, Lerman BB, Kron IL, Sellers TD. Sustained ventricular tachyarrhythmias within 2 months of acute myocardial infarction: Results of medical and surgical therapy in patients resuscitated from the initial episode. J Am Coll Cardiol. 1985;6(4):759-768.

55. Stambler BS, Akosah KO, Mohanty PK, Wood MA, Ellenbogen KA Myocardial ischemia and induction of sustained ventricular tachyarrhythmias: Evaluation using dobutamine stress echocardiographyelectrophysiologic testing. J Cardiovasc Electrophysiol. 2004;15(8): 90I-907.

56. Gressin V, Louvard $\mathrm{Y}$, Pezzano M, Lardoux $\mathrm{H}$. Holter recording of ventricular arrhythmias during intravenous thrombolysis for acute myocardial infarction. Am J Cardiol. 1992;69(3): 152-159.

57. Gorgels APM, Vos MA, Letsch IS, Verschuuren EA, Bär FW, Janssen $\mathrm{JH}$, Wellens $\mathrm{HJ}$. Usefulness of the accelerated idioventricular rhythm as a marker for myocardial necrosis and reperfusion during thrombolytic therapy in acute myocardial infarction. Am J Cardiol. 1988;6 I (4):23I-235.

58. Miller FC, Krucoff MW, Satler LF, Green CE, Fletcher RD, Del Negro AA, Pearle DL, Kent KM, Rackley CE. Ventricular arrhythmias during reperfusion. Am Heart J. 1986; I 12(5):928-932.

59. Yoshida $Y$, Hirai M, Yamada T, Tsuji $Y$, Kondo T, Inden $Y$, Akahoshi M, Murakami Y, Tsuda M, Tsuboi N, Hirayama H, Okamoto M, Ito T, Saito $H$, Toyama J. Antiarrhythmic efficacy of dipyridamole in treatment of reperfusion arrhythmias: Evidence for cAMP-mediated triggered activity as a mechanism responsible for reperfusion arrhythmias. Circulation. 2000; I0I(6):624-630.

60. Wehrens XHT, Doevendans PA, Oude Ophuis TJ, Wellens HJJ. A comparison of electrocardiographic changes during reperfusion of acute myocardial infarction by thrombolysis or percutaneous transluminal coronary angioplasty. Am Heart J. 2000;139(3):430-436.

61. Aplin M, Engstrøm T, Vejlstrup NG, Clemmensen P, Torp-Pedersen C, Køber L. Prognostic importance of complete atrioventricular block complicating acute myocardial infarction. Am J Cardiol. 2003; 92(7):853-856.

62. Kourtesis P, Lichstein E, Chadda KD, Gupta PK. Incidence and significance of left anterior hemiblock complicating acute inferior wall myocardial infarction. Circulation. 1976;53(5):784-787.

63. Kim KH, Jeong MH, Ahn Y, Kim YJ, Cho MC, Kim W, Other Korea Acute Myocardial Infarction Registry Investigatorset. Differential Clinical Implications of High-Degree Atrioventricular Block Complicating ST-Segment Elevation Myocardial Infarction according to the Location of Infarction in the Era of Primary Percutaneous Coronary Intervention. Korean Circ J. 2016;46(3):315-323.

64. Granier M, Massin F, Pasquie J-L. Pro- and Anti-Arrhythmic Effects of Anti-Inflammatory Drugs. Antiinflamm Antiallergy Agents Med Chem. 2013;12(1):83-93.

65. Koyama T, Tada H, Sekiguchi $Y$, Arimoto T, Yamasaki H, Kuroki K, Machino T, Tajiri K, Zhu XD, Kanemoto-Igarashi M, Sugiyasu A, Kuga $\mathrm{K}$, Nakata $Y$, Aonuma K. Prevention of atrial fibrillation recurrence with corticosteroids after radiofrequency catheter ablation: A randomized controlled trial. J Am Coll Cardiol. 20 I0;56(I8): I463-I472.

66. Cheruku KK, Ghani A, Ahmad F, Pappas P, Silverman PR, Zelinger A, Silver MA. Efficacy of nonsteroidal anti-inflammatory medications for prevention of atrial fibrillation following coronary artery bypass graft surgery. Prev Cardiol. 2004;7(I):13-18. 